worship of Isis attracted large numbers to her temple, and the principal services took place before daybreak. The curtains were drawn aside and the statue of the goddess was presented to her worshippers, who straightway prayed to her; an hour after sunrise a hymn was sung to the rising sun, typified by Harpocrates, and the service was over. The second service of the day was held two hours after noon, and it seems to have consisted in the adoration of water in a vessel which was supposed to have been taken from the Nile. Whatever the details may have been, the services certainly had reference to scenes connected with the finding of the dead body of Osiris by his wife Isis, and they were intended to urge the beholder to renounce the present life and to prepare for a second birth into a purified and beatified state of existence in a new world. The temple of Isis at Pompeii is a remarkable relic of the adoption of a remarkable religion by the Romans, and we hope that Prof. Mau will add any new facts which he may glean from subsequent researches to the future editions of his work. The second part of Prof. Mau's volume deals with the houses of Pompeii, and it seems to us to be the best in the book, for it recalls the scenes and occurrences in the daily household life of the Pompeians in a most realistic fashion. The mind's eye has so many facts supplied to it with such lucid explanations that a street of houses appears before it without fatigue, and as the result of but little effort. Parts iii.-vi. deal with trades and occupations, the tombs, Pompeian art and inscriptions; the chapters of these sections are written in the same easy style, but at the same time the reader feels that he is being led along an interesting path by the hand of a master of his craft.

\section{THE UNVEILING OF THE HUXLEY MEMORIAL STATUE.}

THE statue, by Mr. Onslow Ford, R.A., of the late Right Hon. Thomas Henry Huxley, now placed in the first right-hand recess of the Great Hall of the Natural History Museum, was unveiled by H.R.H. the Prince of Wales on Saturday last, April 28, the ceremony being performed, by his Royal Highness's desire, immediately after the meeting of the Trustees appointed for that day.

Seating accommodation had been provided for the Huxley family, the Trustees of the British Museum, the members of the Memorial Committee, and other distinguished guests and chief subscribers to the Memorial Fund, in front of the statue; and a still greater number of persons, most of whom were subscribers also, assembled in the corridors overlooking the Great Hall, and on the staircases.

There were from 700 to 800 persons present, adequately representative of all branches of science, art, law, music, and politics, and of several foreign nations. The following is a classified list of the persons more directly concerned in the ceremony :-

\section{Trustees of the British Museum.}

H.R.H, the Prince of Wales. Earl of Elgin, K.G.

Earl of Hopetoun.

Viscount Cross.

The Bishop of Winchester.

The Lord Walsingham.

The Right Hon. Sir George Trevelyan, Bart.

The Right Hon. John Morley, M.P.

Sir Nathaniel Lindley, Master of the Rolis.

$$
\text { No. I 592, vOL. } 62]
$$

Executive Committee of the Memorial Fund and others.

Lord Shand (Chairman). Sir Joseph Fayrer, Bart., K.C.S.I., F.R.S.

Sir Henry Thompson, Bart. Sir Joseph Hooker, G.C.S.I., C. B., F.R.S.

Sir John Donnelly, K.C.B.

Sir Norman Lockyer, K.C. B., F.R.S.

Sir Michael Foster, K.C.B., M.P., F.R.S.

Sir Spencer Walpole, K.C.B.

Sir A. Geikie, F.R.S.

Mr. Briton Riviere, R.A.

Among other persons who were seated in the central enclosure were the following :-

Sir F. Abel, Bart., F.R.S.

Prof. T. Clifford Allbutt,

M.D., F.R.S.

Sir L. Alma-Tadema, R.A.

Sir Edwin Arnold, K.C.I.E.,

C.S.I.

The Attorney-General.

Mr. Alfred Austin.

Sir Squire Bancroft.

Hon. Edmund Barton, Q.C.

Prof. Bastian, F.R.S.

Sir Lowthian Bell, Bart., F. R.S. Mr. Horace Brown, F.R.S.

Sir T. Lauder Brunton, M.D., F.R.S.

Rt. Hon. L. Courtney, M.P.

Sir Wm. Crookes, K.C.B.,

F.R.S.

Mr. Francis Darwin, F.R.S

The Earl of Ducie, F.R.S.

Sir W. Thiselton - Dyer, K.C.M.G., F.R.S.

Mr. R. Etheridge, F.R.S

Prof, J. B. Farmer, M.A.

Lady Flower.

Prof. Le Neve Foster, F.R.S.

Dr. R. Garnett, C. B.

Dr. J. H. Gladstone, F.R.S.

Lieut.-Col. Godwin-Austen,

F.R.S.

Dr. A. Günther, F.R.S.

Mr. G. Henschel.

Foreign nationalities were represented by :-

Dr. F. P. Moreno (of the Argentine Republic).

Major Dr. von Wissmann Germany).

Mons. L. Geoffray (France)

Mons. F. Fuchs (Congo Free State).

Prof. Batalha Reis (Portugal).

Lord Hobhouse, K.C.S.I., C.I.E.

Prof. Victor Horsley, F.R.S.

Prof. J. W. Judd, C.B., F.R.S.

Right Hon. W. E. H. Lecky,

M.P.

Sir Hugh Low, G.C.M.G.

Dr. P. Manson.

Dr. Ludwig Mond, F.R.S

Prof. R. Meldola, F.R.S.

Sir Francis Mowatt, K.C.B.

Sir Andrew Noble, K.C.B., F.R.S.

Admiral Sir Erasmus Ommanney, Bart., C.B., F.R.S.

Prof. J. Perry, F.R.S.

Sir W. C. Roberts-Austen, K.C.B., F.R.S.

Sir Henry Roscoe, F.R.S.

Prof. A. W. Rücker, F.R.S.

Sir J. S. Burdon-Sanderson, Bart., F.R.S.

Dr. D. H. Scott, F.R.S.

Sir G. G. Stokes, Bart., F. R.S.

Prof. G. Johnstone Stoney,

F.R.S.

Mr. J. J. H. Teall, F.R.S.

Prof. T. E. Thorpe, F.R.S

Prof. W. A. Tilden, F.R.S.

Rev. Canon Tristram, F.R.S.

Sir William Turner, F.R.S.

Prof.W. F. R. Weldon, F.R.S.

Prof. G. Paladino (of Naples). Prof. G. Gilson (of Louvain).

Señor Don Pedro Jovar y Tovar (Spain).

Count Bottaro Costa (Italy).

Plenipotentiaries at the International Conference for the preservation of wild animals in Africa.

Punctually at the time appointed (I.I5 p.m.), his Royal Highness took up a position to the spectators' left of the statue, supported by the Standing Committee of the Trustees of the Museum, with Sir Maunde Thompson and Prof. Ray Lankester; while Sir Joseph Hooker, similarly supported by the members of the Executive of the Memorial Committee, stood on the right ; the sculptor, $\mathrm{Mr}$. Onslow Ford, being in proximity to the statue.

The proceedings were opened by Prof. Ray Lankester, with the following introductory statement :-

Your Royal Highness, My Lords, LAdies and Gentlemen,-The duty of briefly explaining the nature of the present proceedings has devolved upon me. I feel it to be a great privilege to discharge this duty on the occasion designed to do honour to my venerated master, Prof. Huxley. \& This 
celebration would have been no less dear to Huxley's fellow. worker and friend, the late director of this museum, Sir William Flower, who unhappily is no longer with us to witness the completion of the memorial statue which he, especially, desired to see placed in this hall.

A few months after Prof. Huxley's death in I895, a committee was formed for the purpose of establishing a memorial of the great naturalist and teacher. At a meeting of that committee, held on November 27,1895 , at which 250 members were present, and at which his Grace the Duke of Devonshire presided, the following resolution was carried :-

"That the memorial do take the form of a statue, to be placed in the Museum of Natural History, and a medal in connection with the Royal College of Science; and that the surplus be devoted to the furtherance of biological science in some manner to be hereafter determined by the committee, dependent upon the amount collected."

From all parts of the world, besides our own country, from every State of Europe, from India and the remotest Colonies, and from the United States of America, subscriptions have been received for the Huxley memorial, amounting in all to more than $3380 l$.

Three years ago the committee commissioned and obtained the execution of a medal bearing the portrait of Huxley, and has established its presentation as a distinguished reward in the Royal College of Science. The re-publication of the complete series of Huxley's scientific memoirs, which was proposed as one of the memorials to be carried out by the committee, has been undertaken by Messrs. Macmillan, without assistance from the committee. I am glad to be able to state that two large volumes of these richly illustrated contributions to science have been already published.

Whilst these other memorials were in progress under the auspices of the executive committee, they secured the services of Mr. Onslow Ford, R.A., to execute the statue which it had been decided by the general committee to regard as the chief object of the subscriptions entrusted to them. On the completion of the statue, the trustees of the British Museum agreed to receive it and to place it in the great hall where we are now assembled.

On behalf of the vast body of subscribers to the memorial, Sir Joseph Hooker, Huxley's oldest and closest friend, himsel the survivor of that distinguished group of naturalists, including Charles Lyell, Richard Owen and Charles Darwin, who shed so much lustre on English science in the Victorian age, will hand over the statue of Huxley to the trustees of the British Museum. Your Royal Highness has been graciously pleased, as one of the trustees, to represent them on the present occasion, and to receive the statue on their behalf. The memorial statue of Huxley is the expression of the admiration, not only of the English people, but of the whole civilised world, for one who as discoverer, teacher, writer and man, must be reckoned among the greatest figures in the records of our age.

Sir Joseph Hooker then stepped forward from among the committee, and presented the statue in the following words:-

May iT Please Your Royal Highness, - I have the honour of being deputed, by the subscribers to the statue of my friend the late Prof. Huxley, to offer it to your Royal Highness, on behalf of the trustees of the British Museum, with the intent that it should be retained in this noble hall as a companion to the statues of Prof. Huxley's distinguished predecessors, Sir Joseph Banks, Mr. Darwin and Sir Richard Owen. It would be a work of supererogation, even were I competent to do so, to dwell upon Prof. Huxley's claims to so great an honour, whether as a profound scientific investigator of the first rank, as a teacher, or as a public servant; but I may be allowed to indicate a parallelism between his career and those of two of the eminent naturalists to whom I have alluded, which appears to me to afford an additional argument in favour of retaining his statue in proximity to theirs. Sir Joseph Banks, Mr. Darwin and Prof. Huxley all entered upon their effective scientific careers by embarking on voyages of circumnavigation for the purpose of discovery and research under the flag of the Royal Navy. Sir Joseph Banks and Prof. Huxley were both Presidents of the Royal Society, were both trustees of the British Museum ; and, what is more nutable by far, so highly were their scientific services estimated by the Crown and their country, that they both attained to the rare honour of being called to seats in the Privy Councils of their respective Sovereigns.

No. I 592, vOL. 62]
With these few words I would ask your Royal Highness graciously to accede to the prayer of the subscribers to this statue, and receive it on behalf of the trustees of the British Museum.

He was followed by Sir Michael Foster, who pronounced the following éloge on Huxley's work and influence :-

May it Please Your Royal Highness,-Before you unveil this statue it is my duty and privilege to add a few words to those which have just been spoken by the beloved Nestor of biological science. Sir Joseph D. Hooker, born before Huxley was born, a sworn comrade of his in the battle of science, standing by him and helping him like a brother all through his strenuous life, may perhaps be allowed to shrink from saying what he thinks of the great work which Huxley did.

We of the younger generations, Huxley's children in science, who know full well that anything we may have been able to do springs from what he did for us, cannot on this great occasion be wholly silent.

Some of us have at times thought that Huxley gave up for mankind much which was meant for the narrower sphere of science; but if science may seem to have been thereby the loser, mankind was certainly the gainer; and indeed it was a gain to science itself to be taught that her interests were not hers alone, and that not by one tie or by two, but by many was her welfare bound up with the common good of all.

To many perhaps the great man whose memory we are here met to honour was known chiefly as the brilliant expositor of the far-reaching views of that other great man who through his statue is now looking down upon us. Your Royal Highness is doubtless at this moment thinking of that interesting occasion fifteen years ago, when you unveiled that statue of Darwin, and you are calling to mind the weighty words then spoken by him whose own statue brings us here to-day.

Huxley it is true fought for Darwin, and indeed "he was ever a fighter." But he fought not that Darwin might prevail ; he fought for this alone-that the views which Darwin had brought forward might be examined solely by the clear light of truth, untroubled by the passion of party or by the prejudice of preconceived opinion. As he never claimed for those views the infallibility of a new gospel, so he always demanded that they should not be peremptorily set aside as already proved to be wrong.

Huxley worked for his fellow men in many ways other than the way of quiet scientific research. Had we not known this we should have thought that his whole life had been given up to original scientific investigation, so much has the progress of biologic science, since he put his hand to it, been due to his labours. On the sands of many a track of biologic inquiry he has left his footprint, and his footprint has ever been to those coming after him a token to press on with courage and with hope. The truths with which he enriched science are made known in his written works; but that is a part only of what he did for science. No younger man, coming to him for help and guidance, ever went empty away; and we all-anatomists, zoologists, geologists, physiologists, botanists, and anthropologists-came to him. The biologists of to-day, all of us, not of this country alone, but of the whole world of science, forming, as it were, a scattered fleeting monument of this great man, are proud at the unveiling of this visible lasting statue here.

In conclusion, Sir M. Foster, facing the Prince, added the words :- May I crave your Royal Highness's permission to seize this opportunity to assure you incidentally, but none the less from the bottom of our hearts, on the part of men of science that we, in common with all Her Majesty's subjects, are rejoicing that you escaped the dreadful peril to which a few days back you were exposed, and to express to you our continued esteem and respect?

On Sir M. Foster's return to his seat among the committee, the Duke of Devonshire, speaking from in front of the veiled statue, said he had the honour nearly five years ago of presiding over the committee formed for the purpose of establishing a memorial to Prof. Huxley. He had now to report to his Royal Highness that the labours of that committee had terminated, and to say that the committee desired to present the statue to his Royal Highness on behalf of the trustees of the British Museum. They felt, however, that the real memorial to the deceased man of science was to be found in the writings which had aiready been referred to, and still more in the scientific work he accomplished or helped to promote, and in the influence he exercised and was still exercising upon the 
minds of younger men, many of whom they trusted might at some future time emulate his distinguished example. On behalf the committee he begged to tender his Royal Highness their thanks for having come to give a final sanction to their proceedings, and for having undertaken the duty of unveiling the statue that day.

The Prince of Wales then withdrew the covering from the statue, and brought the proceedings to a close with the following words :-

My LORDs, LAdies and Gentlemen,-I consider it a very high compliment to have been asked by the Huxley Memorial Committee to unveil and receive this statue, and to do so in the name of the trustees of the British Museum, of whom I have the honour to be one. I have not forgotten that fifteen years ago I performed a similar duty in connection with the fine statue of the celebrated Charles Darwin, which is at the top of the stairs, when it was similarly handed over to the British Museum. We have heard to-day most eloquent and interesting speeches with reference to that illustrious man of science and the great thinker, the late Prof. Huxley. It would, therefore, be both superfluous of me, I may even say unbecoming in me, to sound his praises here in the presence of so many men of science, who know more about all his work than I do. I can only, on my own behalf, endorse everything that has fallen from the lips of those gentlemen who have spoken, and I beg to repeat the expression of the great pleasure it has given me for the second time to have performed the interesting ceremony of taking over the statue of another great and illustrious man of science.

The statue is a colossal seated one of white marble, the figure being represented in a doctor's gown, with the right hand clasping one arm of the chair, and the left lying across the other with the fist clenched. The pedestal is of Verona marble on a black base, and bears upon its face the name and dates of birth and death in simple bronze letters.

The statue is a thoroughly successful work of art, and stands out in bold relief to the dim mystery of the recess in which it is placed. Though the expression of the face is perhaps a little severe, the features are true to nature; and when it is considered that the artist was never privileged with a sitting in life, and that the only material available to him were the death mask and an assemblage of none too favourable photographs, it must be admitted he has done well. Great praise must be given to the modelling of the hands, in which those who knew the great philosopher intimately will recognise a faithful portrayal of well-defined characteristics.

The first and main object of the Memorial has thus been successfully achieved. As for those which remain, the award at the Royal College of Science is to be known as the "Huxley Gold Medal," for the "promotion of science in the directions in which Huxley was distinguished," and especially for research to be carried on in the laboratory which bears his name. It has been further arranged that the use of the obverse die shall be granted to the Anthropological Institute (of which Huxley was practically the founder), in connection with the establishment by that body of a Huxley Lectureship, and a medal, for which they will furnish the re verse. Huxley's labours as an anthropologist are among the most important of his scientific career, and it may be questioned whether his "Man's Place in Nature," published against the advice of some of his friends, who feared his "ruin" did it appear, does not now rank among the best and most enduring of his works. His influence as an anthropologist was great, and devotees to that branch of science will hail with satisfaction this decision to perpetuate his memory.

PRELIMINARY NOTES ON THE RESULTS OF THE MOUNT KENYA EXPEDITION, 1899.

THE Mount Kenya Expedition left Nairobi, the then head of the Uganda Railway, on July 26 , I899, and returned to Naivasha, a station on the Uganda Road, on September 29. Considerable difficulties were experienced in the nuatter of commissariat, on account of the drought and famine prevalent throughout East Africa. For this reason a longer sojourn on the mountain would have been impracticable, even if other circumstances had permitted of it.

Previous accurate knowledge of Mount Kenya rested chiefly on the work of Captain G. E. Smith, R.E., who had fixed the position of the peak, by triangulation along the Uganda Road, and of Dr. J. W. Gregory, who, in I893, ascended the south-western slope to a height which appears to have been nearly 16,000 feet. An account of the 1899 journey is given in the May number of the Geographical Journal.

Mount Kenya is a vast flattened dome, seered with radiating valleys. It rises from a plateau, the level of which is 5000 to 7000 feet above the sea. Upon the crown of the dome is a precipitous pyramid, the cleft peak of which has an altitude of 17,200 feet. The entire massif measures about fifty miles from east to west and forty miles from north to south. Its northern slopes are crossed by the equator.

We made a plane table survey of the central portion of the mountain, and connected it by route surveys with Nairobi and Naivasha. The altitude of the central peak was determined by boiling point and theodolite, combined in four different ways, with an average result practically the same as that obtained by Captain Smith at a distance of ninety miles.

The central pyramid is the core of the denuded and dissected volcano, a fact first suggested by the late Joseph Thomson, who saw the mountain from the Laikipian plateau. Although not yet examined in section, the holocrystalline rock on the summit may probably be identified with the nepheline syenite obtained by Gregory at a lower level. The core must, therefore have risen considerably above the present peak, and if allowance be made for still loftier crater-walls, the original height of Kenya may have equalled that of the still complete Kibo summit of Kilimanjaro.

The most significant point in the structure of the mountain is the fact that, while the major axis of the peak strikes west-north-westward and throws the glaciers down northern and southern slopes, the chief waterparting runs in a direction at right angles to this, past the eastern foot of the central peak, with the effect that the valleys are thrown off eastward and westward, and that all the existing glaciers belong to the westward drainage. From a series of rock specimens obtained at widely separated spots on the summit of the craggy ridge constituting the divide, it appears that the lie of the water-parting has been determined by a system of great dykes, which must almost have split the mountain in two.

There are fifteen existing glaciers, of which two are a mile in length, and the remainder are small. Their lower ends descend to about 14,800 feet. Everywhere and at all hours at the time of our visit the surfaces were dry and crisp. Comparatively little water flowed from them, and the stream banks below gave small indication of floods. The ice was intensely hard, and fed by fine hail rather than snow. These facts may be explained by the meteorological conditions. Although the air-temperatures were not very low at night, there was then great radiation into the cloudless sky. In the afternoon, on the other hand, a cloud cap regularly warded off the sunshine. The air was usually dry, the relative humidity falling on more than one occasion to 54 per cent.

Evidence of past glaciation was frequent down to 12,000 feet both in the eastern and western valleys, and there were occasional traces down to about 9000 feet. The whole of the central part of the mountain, with the exception of the peak and the dividing ridge, must have been buried under a sheet of glacier, more than comparable to that of Kilimanjaro, at a time later than the erosion of the existing valleys.

NO. I 592 , VOL. 62 ] 